\title{
New genotypes of white spot syndrome virus (WSSV) and Taura syndrome virus (TSV) from the Kingdom of Saudi Arabia
}

\author{
Kathy F. J. Tang*, Solangel A. Navarro, Carlos R. Pantoja, Fernando L. Aranguren, \\ Donald V. Lightner
}

Department of Veterinary Science and Microbiology, University of Arizona, Tucson, Arizona 85721, USA

\begin{abstract}
White spot syndrome virus (WSSV) and Taura syndrome virus (TSV) are highly pathogenic to penaeid shrimp and have caused significant economic losses in the shrimp culture industry around the world. During 2010 and 2011, both WSSV and TSV were found in Saudi Arabia, where they caused severe mortalities in cultured Indian white shrimp Penaeus indicus. Most outbreaks of shrimp viruses in production facilities can be traced to the importation of infected stocks or commodity shrimp. In an attempt to determine the origins of these viral outbreaks in Saudi Arabia, we performed variable number of tandem repeat (VNTR) analyses for WSSV isolates and a phylogenetic analysis for TSV isolates. From the WSSV genome, the VNTR in open reading frames (ORFs) 125 and 94 were investigated with PCR followed by DNA sequence analysis. The genotypes were categorized as $\left\{\mathrm{N}_{125}, \mathrm{~N}_{94}\right\}$ where $\mathrm{N}$ is the number of repeat units in a specific ORF, and the subscript indicates the ORF (i.e. ORFs 125 and 94 in this case). From 15 Saudi Arabia WSSV isolates, we detected 3 genotypes: $\left\{6_{125}, 7_{94}\right\},\left\{7_{125}, \operatorname{del}_{94}\right\}$, and $\left\{8_{125}, 1_{94}\right\}$. The WSSV genotype of $\left\{7_{125}\right.$, del $\left.{ }_{94}\right\}$ appears to be a new variant with a 1522 bp deletion encompassing complete coding regions of ORF 94 and ORF 95 and the first 82 bp of ORF 93. For TSV genotyping, we used a phylogenetic analysis based on the amino acid sequence of TSV capsid protein 2 (CP2). We analyzed 8 Saudi Arabian isolates in addition to 36 isolates from other areas: SE Asia, Mexico, Venezuela and Belize. The Saudi Arabian TSV clustered into a new, distinct group. Based on these genotyping analyses, new WSSV and TSV genotypes were found in Saudi Arabia. The data suggest that they have come from wild shrimp Penaeus indicus from the Red Sea that are used for broodstock.
\end{abstract}

KEY WORDS: Virus genotyping $\cdot$ WSSV $\cdot$ TSV $\cdot$ Penaeus indicus $\cdot$ VNTR analysis

\section{INTRODUCTION}

Viral diseases have caused significant economic losses for the shrimp farming industry around the world. Among these, white spot syndrome virus (WSSV) is the most serious threat; economic losses in production and trade have been reported to approach US\$10 billion (Stentiford et al. 2009, Lightner 2011). Taura syndrome virus (TSV) is the second most important virus, which has caused approximately US\$1.5 to 3 billion in losses (Lightner 2011).
WSSV and TSV are both extremely virulent, and infection can result in high (40 to $100 \%$ ) mortalities in populations of farmed shrimp. WSSV is a large (70 to $150 \times 275$ to $380 \mathrm{~nm}$ ), enveloped, doublestranded (ds) DNA virus with a genome size of over $300 \mathrm{~kb}$ (Van Hulten et al. 2001, Yang et al. 2001). TSV is a small, non-enveloped, ssRNA virus with a genome size of $10 \mathrm{~kb}$ (Mari et al. 2002). Both viruses were first reported around 1991 to 1992; WSSV was originally found in SE Asia (Huang et al. 1994, Inouye et al. 1994) and TSV initially appeared in 
Ecuador (Lightner et al. 1995). These viruses spread quickly, and epidemics were occurring throughout the world by the late 1990s. During 2010 and 2011, both WSSV (OIE 2011a) and TSV were detected in the Kingdom of Saudi Arabia, where they have severely affected shrimp production.

To better understand the origins and the spread of these viruses within Saudi Arabia, we applied molecular genotyping to characterize viral isolates collected from infected populations. Both viruses have been detected in almost all the major shrimp farming countries, and genotyping methods have been developed to characterize and differentiate among geographic isolates. WSSV genotyping is based on the variable number of tandem repeat (VNTR) analyses within open reading frame (ORF) 125 (69 bp for each repeat unit [RU]) and ORF 94 (54 bp per RU). These VNTR analyses have been used in several epidemiological studies (Wongteerasupaya et al. 2003, Dieu et al. 2004, Hoa et al. 2005, Pradeep et al. 2008, Muller et al. 2010, Walker et al. 2011a,b). For TSV genotying, the capsid protein 2 (CP2) coding region varies among isolates and its sequence has been used for phylogenetic analysis (Tang \& Lightner 2005, Wertheim et al. 2009).

In this study, we applied the VNTR analyses to characterize WSSV genotypes among 15 Saudi Arabian isolates and conducted a phylogenetic analysis to determine whether $8 \mathrm{TSV}$ isolates clustered with the previously determined groups.

\section{MATERIALS AND METHODS}

\section{Shrimp samples}

Samples of Indian white shrimp Penaeus indicus (taxonomy according to Holthuis 1980) were collected from 4 shrimp farms (Farms A to D, Fig. 1) in Saudi Arabia during 2010 to 2011. One P. monodon sample from Mozambique (collected from the India Ocean) in 2011 was also included in this study. Each sample consisted of pleopods, or gills, or whole shrimp sampled from 1 to 5 individual shrimp. These were preserved in $95 \%$ ethanol and sent to the Aquaculture Pathology Laboratory at the University of Arizona for PCR (or reverse transcription PCR, RTPCR) analyses for the presence of white spot syndrome virus (WSSV) and Taura syndrome virus (TSV). The presence of viruses was determined by PCR (RT-PCR) using methods recommended by the Office International des Epizooties (OIE 2011b); procedures are described in the following section. For

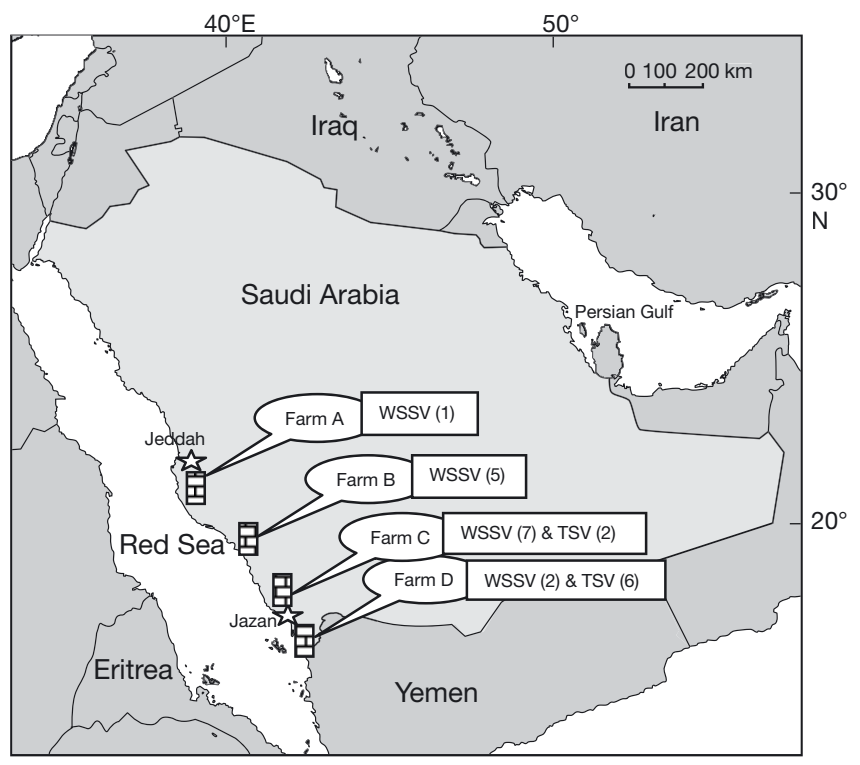

Fig. 1. Location of the 4 shrimp farms in Saudi Arabia. Boxes indicate where the viruses, WSSV and TSV, were detected and the numbers in parentheses indicate the number of samples taken for analysis of their genotypes

genotyping of WSSV and TSV, 16 WSSV (including 1 Mozambique isolate, see Table 1) and 8 TSV representative isolates were analyzed. TSV isolates were designated by the country (e.g. SA: Saudi Arabia) and year of collection (e.g. 11: 2011); SA/11a and $\mathrm{SA} / 11 \mathrm{c}$ were from Farm $\mathrm{C}$, the remaining 6 isolates were from Farm D.

\section{DNA extraction, WSSV PCR analysis and genotyping}

Total DNA was extracted with a Maxwell-16 Cell LEV DNA purification kit (Promega) using the Maxwell 16 system (Promega). For WSSV detection, a nested PCR was performed with PuReTaq ${ }^{\mathrm{TM}}$ ReadyTo-Go ${ }^{\mathrm{TM}}$ PCR beads (GE Healthcare). Each reaction (final volume: $25 \mu \mathrm{l}$ ) contained $1 \mu \mathrm{l}$ of extracted DNA (at concentrations of 100 to $300 \mathrm{ng} \mathrm{\mu l}^{-1}$ ), $2.5 \mathrm{U}$ of PuReTaq $^{\mathrm{TM}}$ DNA polymerase, $10 \mathrm{mM}$ Tris- $\mathrm{HCl}$, $\mathrm{pH} 9.0,50 \mathrm{mM} \mathrm{KCl}, 1.5 \mathrm{mM} \mathrm{MgCl}_{2}, 0.2 \mathrm{mM}$ each of the dNTPs and $0.2 \mu \mathrm{M}$ WSSV primers (first step primers: 146F1/R1, second step primers: 146F2/R2; OIE 2011b). Amplifications (both first and second step) were performed in a DNA thermocycler (Applied Biosystems) as follows: initial denaturation at $94^{\circ} \mathrm{C}$ for $2 \mathrm{~min}$, followed by 30 cycles of $94^{\circ} \mathrm{C}$ for $30 \mathrm{~s}, 62^{\circ} \mathrm{C}$ for $30 \mathrm{~s}$ and $72^{\circ} \mathrm{C}$ for $30 \mathrm{~s}$, and a final extension at $72^{\circ} \mathrm{C}$ for $2 \mathrm{~min}$. Following this, an aliquot of the PCR mixture was analyzed in a $1.2 \%$ agarose gel 
containing ethidium bromide and then photographed with an AlphaImager gel documentation system (Alpha Innotech).

For WSSV VNTR analysis within the ORF 125 region, PCR was performed using the Ready-To$\mathrm{Go}^{\mathrm{TM}}$ PCR beads with primers ORF 125-flank (forward: 5'-CGA AAT CTT GAT ATG TTG TGC-3', reverse: 5'-CCA TAT CCA TTG CCC TTC TC-3'; Dieu et al. 2004). For VNTR analysis in ORF 94, we used primers ORF 94-F (5'-TCT ACT CGA GGA GGT GAC GAC-3') and ORF 94-R (5'-AGC AGG TGT GTA CAC ATT TCA TG-3'; Wongteerasupaya et al. 2003). For WSSV isolates showing a deletion in ORF 94, primers ORF 93-F1 (5'-CGC CCT ATT ACC ATT GAT GC-3') and ORF 96-R1 (5'-GCA ACA AAT TCC CCT TTC AA-3') were used. Amplification was performed as follows: initial denaturation at $94^{\circ} \mathrm{C}$ for $5 \mathrm{~min}$, followed by 35 cycles of $94^{\circ} \mathrm{C}$ for $30 \mathrm{~s}, 55^{\circ} \mathrm{C}$ for $30 \mathrm{~s}$ and $72^{\circ} \mathrm{C}$ for $1 \mathrm{~min}(1.5 \mathrm{~min}$ for primers ORF 93F1/ORF 96-R1), and a final extension at $72^{\circ} \mathrm{C}$ for $7 \mathrm{~min}$. PCR results were visualized as described above. The PCR products were purified with the QIAquick PCR purification kit (Qiagen), and DNA sequencing was performed by the Genomic Analysis and Technology Core facility at the University of Arizona using Sanger sequencing (Applied Biosystems 3730 DNA Analyzer).

From the nucleotide sequence, the number of tandem repeats within the ORFs 125 and 94 were analyzed with the Tandem Repeats Finder program (Benson 1999).

\section{Total RNA extraction, TSV CP2 RT-PCR and phylogenetic analysis}

Total RNA was extracted with a Maxwell 16 Tissue LEV total RNA Purification kit (Promega) using the Maxwell 16 system. The presence of TSV was determined by a RT-PCR using the GeneAmp rTth RTPCR (Applied Biosystems) and TSV primers 9195/ 9992 described in OIE (2011b). The extracted RNA was reverse transcribed at $60^{\circ} \mathrm{C}$ for $30 \mathrm{~min}$, and the PCR was initiated at $94^{\circ} \mathrm{C}$ for $2 \mathrm{~min}$, followed by 40 cycles of $94^{\circ} \mathrm{C}$ for $15 \mathrm{~s}, 60^{\circ} \mathrm{C}$ for $1 \mathrm{~min}$, ending with $60^{\circ} \mathrm{C}$ for $5 \mathrm{~min}$. For TSV genotyping, a RT-PCR was performed with a SuperScript one-step RT-PCR system with Platinum Taq DNA polymerase (Invitrogen). The CP2 region of the TSV genome was amplified with primers TSV-7879F (5'-CAA GCC TGT TTC CTG GGT GTC-3') and TSV-9251R (5'-GCT CAT TTA CTG TGA TAT CTT GAT TTG-3'). The RT-
PCR profile was $30 \mathrm{~min}$ at $55^{\circ} \mathrm{C}$, followed by 40 cycles of $94^{\circ} \mathrm{C}$ for $30 \mathrm{~s}, 55^{\circ} \mathrm{C}$ for $30 \mathrm{~s}$ and $68^{\circ} \mathrm{C}$ for $1.5 \mathrm{~min}$. The amplified products were visualized, excised and purified for DNA sequencing as described in the previous section.

Amino acid sequences translated from the TSV $\mathrm{CP} 2$ region of 8 isolates from Saudi Arabia were used to construct a phylogenetic tree with 36 other TSV isolates.

The phylogenetic analysis was performed with MEGA v. 5 using the neighbor-joining (NJ) method (Tamura et al. 2011). The data were resampled by 5000 bootstrap replicates to determine the confidence indices. The CP2 sequences of 8 Saudi Arabian isolates are deposited in the GenBank under accession numbers JQ356858 to JQ356865. Information on, and GenBank numbers of, the other $36 \mathrm{CP} 2$ sequences are given in Wertheim et al. (2009).

\section{RESULTS}

\section{WSSV and TSV outbreaks in Saudi Arabia}

During 2010 to 2011, Penaeus indicus were collected from 4 major shrimp farms (Farms A to D, Fig. 1) in Saudi Arabia for monitoring the presence of WSSV and TSV. By PCR, we detected WSSV at all 4 farms. WSSV was first found at Farm A in April 2010, later at Farms B and C around January to February 2011 and then at Farm D in November 2011. WSSV has caused significant mortalities (>95\%) of the cultured shrimp at all these farms.

TSV was first detected by RT-PCR at Farm C in June 2010 and at Farm D around October 2010. At these infected farms, shrimp started showing mortalities $30 \mathrm{~d}$ after stocking, and only 30 to $50 \%$ of shrimp survived at harvest. Taura syndrome disease persisted throughout 2010 and into 2011. The losses in shrimp production increased when WSSV appeared in these farms at the beginning of 2011.

\section{WSSV genotyping: VNTR analyses in ORF 125 and ORF 94}

To characterize the WSSV genotype in Saudi Arabia, 15 WSSV representative isolates were analyzed (Table 1). A Mozambique WSSV sample was included for comparison. We performed the VNTR analysis within the ORF 125, and all 16 samples were detected with specific amplicons at sizes of 652,722 or $792 \mathrm{bp}$. These amplicons were sequenced and analyzed for 
the number of RUs; the results showed 3 types of amplicons with 6, 7 and 8 RUs, respectively (Table 1).

For VNTR analysis in ORF 94, we carried out the PCR with the primers ORF 94-F and ORF 94- $R_{i}$ this

Table 1. Number of repeat units (RUs) found within open reading frame (ORF) 125 and ORF 94 of WSSV isolated from Saudi Arabian shrimp farms (Farms A-D) and from Mozambique (MZ). Consensus sequence of the RU in ORF 125 (69 bp): AG/TAA CAA GGA GGA AGA AGA CGC GAG GAT CAA GCG TGC AGT CGA CAT GGC TGT TGC AGC CAT CAA CGA AA. Consensus sequence of the RU in ORF 94 (54 bp): CGC AAA AAG CGT GCC GCA CCT CCA CCT GAG GAT GAA GAA GAG GAT GAT TTC TAC. Dates are given as mm/dd/yyyy; del: deletion

\begin{tabular}{|lcrrr|}
\hline \multirow{2}{*}{ Isolate no. } & \multicolumn{2}{c}{ No. of RUs } & Farm & Sampling \\
& ORF 125 & ORF 94 & site & date \\
\hline $10-143$ & 6 & 7 & A & $04 / 28 / 2010$ \\
$11-065 / 6$ & 8 & 13 & B & $02 / 05 / 2011$ \\
$11-065 / 7$ & 8 & 13 & B & $02 / 05 / 2011$ \\
$11-102 / 1$ & 8 & 13 & B & $03 / 06 / 2011$ \\
$11-102 / 2$ & 8 & 13 & B & $03 / 07 / 2011$ \\
$11-114$ & 8 & 13 & B & $03 / 14 / 2011$ \\
$11-041 / 20$ & 7 & del & C & $01 / 27 / 2011$ \\
$11-041 / 21$ & 7 & del & C & $01 / 27 / 2011$ \\
$11-041 / 22$ & 7 & del & C & $01 / 27 / 2011$ \\
$11-208 / 3$ & 7 & del & C & $05 / 18 / 2011$ \\
$11-208 / 4$ & 7 & del & C & $05 / 18 / 2011$ \\
$11-208 / 8$ & 7 & del & C & $05 / 18 / 2011$ \\
$11-208 / 15$ & 7 & del & C & $05 / 18 / 2011$ \\
$11-394 / A$ & 7 & del & D & $11 / 22 / 2011$ \\
$11-394 / B$ & 7 & del & D & $11 / 22 / 2011$ \\
$11-312$ & 6 & del & MZ & $09 / 02 / 2011$ \\
\hline
\end{tabular}

showed that only 6 Saudi Arabian WSSV isolates from Farms A and B were positive (Fig. 2A, Lanes 1 to 4 showed representative isolates from each case; the isolate numbers are labeled under each lane) and that 2 types of amplicons were found, with 7 and 13 RUs, respectively (Table 1). The other 9 isolates from Farms $\mathrm{C}$ and $\mathrm{D}$ and the Mozambique isolate were not amplified (Fig. 2A, Lanes 5 to 8). Thus, we selected a new pair of PCR primers (ORF 93-F1 and ORF 96-R1) that targeted the ORF 93 and ORF 96 for amplification; the PCR detected amplicons of $348 \mathrm{bp}$ in size in these samples (Fig. 2B, Lanes 5 to 7) and in the Mozambique sample (Fig. 2B, Lane 8). The ORF 93F1 and ORF 96-R1 primers also amplified the 7 WSSV isolates from Farms A and B with a $\sim 1.0 \mathrm{~kb}$ increment in size (Fig. 2B, Lanes 1 to 4). We sequenced the $348 \mathrm{bp}$ PCR products from isolate no. 11-208/4 (Fig. 2B, Lane 6), and the nucleotide sequence showed deletions in ORF 93 (an 82 bp deletion at $\mathrm{N}$-terminus), in ORF 94 and in ORF 95 (Fig. 3A). We also sequenced the $\sim 2.0 \mathrm{~kb}$ amplicons from isolate no. 11-065/6 (Fig. 2B, Lane 2) and confirmed the presence of 13 RUs within the ORF 94. The alignment of $348 \mathrm{bp}$ (Fig. 2B, Lane 6) with the $1987 \mathrm{bp}$ (Fig. 2B, Lane 2) amplicons showed a 1522 bp deletion (Fig. 3B). Based on these VNTR results, we tentatively designated the WSSV genotype with the number of RU in both ORF 125 and ORF 94 as: $\left\{6_{125}, 7_{94}\right\}$, $\left\{7_{125}\right.$, del $\left._{94}\right\}$ and $\left\{8_{125}, 13_{94}\right\}$ where $\mathrm{N}$ is the number of RUs in a specific ORF (indicated by a subscript), and 'del' stands for deletion.

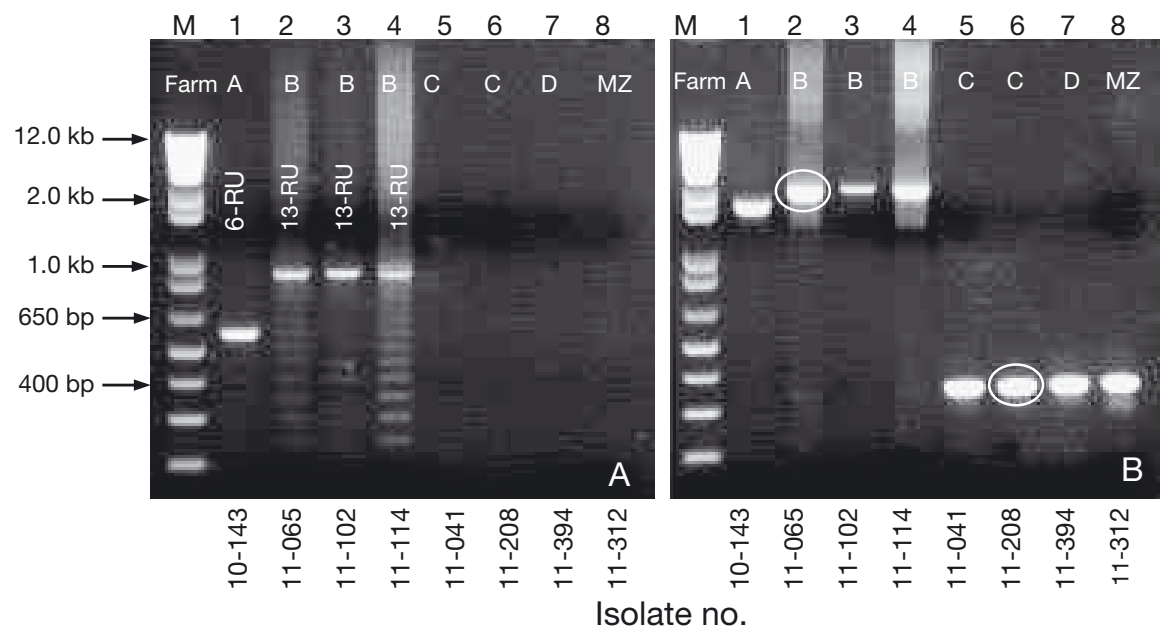

Fig. 2. WSSV genotyping in the ORF 94 region. (A) PCR with primers ORF 94-F and ORF 94-R. (B) PCR using primers ORF 93-F1 and ORF 96-R1, which target sequences $611 \mathrm{bp}$ upstream and $425 \mathrm{bp}$ downstream of the amplicons produced in (A). The PCR products (encircled) from Lane 2 and Lane 6, respectively, were purified and sequenced; their sequences were aligned as shown in Fig. 3B. Lane M: $1 \mathrm{~kb}$ plus ladder molecular weight marker; RU: repeat units; ORF: open reading frame

\section{TSV phylogenetic analysis}

For TSV genotyping, 8 Saudi Arabian isolates were sequenced within the CP2 region; these 8 TSV sequences were very close, with a mean distance of $0.7 \%$. The Saudi Arabian TSV (GenBank no. JX094350) shared 90\% sequence identity with the reference isolate from Hawaii (collected in 1994, GenBank no. AF277675). We determined its genotype by constructing a phylogenetic tree comparing the Saudi Arabian isolates to 36 isolates from other areas; the result revealed 5 major TSV lineages (Fig. 4). All 8 Saudi Arabian isolates clustered into a distinct group, separated from the existing 
A CGCCCTATTACCATTGATGCACAAATTTCCTCCTTCATTCTAATAGCGGCAGA TTGTTTGTCAAAATAACACTCCCTATAGTAACAACCAGGATTTC---- $\Delta----$ AATGCGTGGGCAGAGGCGGAGGTGGTGATAAAGCGTTTCTGAGAAACATTGGG CGTATGACGTCAACTACATTATTCTTCCTCCTCCTCCTCСTCСTATTGCCTCT GCCAGTTCAGTATTTTATTTTTCTTCCTATACAATAAAAAGTATCAGATGAAT ATTTTTACTGTTTTTCTGTTCATCCСTCTTTCCTATTGTAAAAAAACCAATAA CTAACTAATCATGGATAACTTGAAAGGGGAATTTGTTGC

B

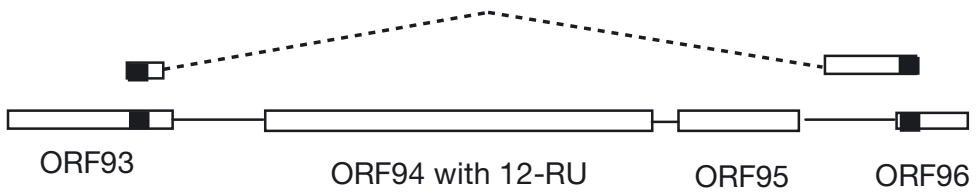

Fig. 3. A PCR fragment amplified from primers, ORF 93-F1 and ORF 96R1, showing deletions in ORFs 94, 95 and 93. (A) Nucleotide sequence of the $348 \mathrm{bp}$ amplicons from WSSV sample no. 11-208/3 (see Fig. 2B, Lane $6)$. (--- $\Delta---)$ : deletion region of ORF 94/95/93; letters in bold are the sequence of primers. (B) Schematic alignment of the WSSV isolate no. 11208/3 (Fig. 2B, Lane 6) to the isolate no. 11-065/6 (Fig. 2B, Lane 2), which

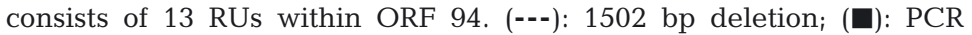
primers ORF 93-F1 and ORF 96-R1. ORF: open reading frame; RU: repeat units

4 groups (Belize, SE Asia, Venezuela and Mexico) by a long internal branch.

These 8 TSV isolates in 2010 to 2011 appeared to have a different origin from a 2007 Saudi Arabian isolate (SA/07, within the Belize lineage in Fig. 4), and from an Eritrean isolate (ER/04, within the Mexico lineage) collected on the west side of the Red Sea in 2004. The ER/04 TSV was introduced from imported Peneaus vannamei postlarvae from Mexico (Wertheim et al. 2009). The origin of SA/07 TSV is not clear.

The reliability of the tree was examined by bootstrap analysis. The Saudi Arabian lineage was highly supported by the bootstrap value of $100 \%$. Among the 8 isolates, 2 were collected from Farm C (SA/11a and SA/11c) and 6 were collected from Farm D, but they all appeared to have the same origin as they were strongly grouped together. Lineages from both Mexico and Belize were also highly supported. The SE Asian and Venezuelan isolates were more heterogeneous but still clustered into their own groups, with bootstrap values of $71 \%$ and $84 \%$, respectively.

\section{DISCUSSION}

Two highly virulent shrimp viruses, WSSV and TSV, have been detected in the Kingdom of Saudi Arabia. To determine the origins of these viruses, we performed genotyping studies and found a new genotype in each of the WSSV and TSV isolates collected.
The WSSV genotyping data did not prove to be particularly useful in determining the origin of WSSV in Saudi Arabian shrimp farms. The WSSV isolates in Farms $A$ and $B$ have genotypes of $\left\{6_{125}, 7_{94}\right\}$ and $\left\{8_{125}, 13_{94}\right\}$, respectively. In both cases, the numbers at each ORF are well within the variability reported for isolates from Asia and Latin America (Wongteerasupaya et al. 2003, Dieu et al. 2004, Hoa et al. 2005, Musthaq et al. 2006, Pradeep et al. 2008, Muller et al. 2010, Walker et al. 2011a,b). However, it is known that Farm A previously (late 1990s) cultured Penaeus monodon imported from SE Asia and that Farms $A$ and $B$ have struggled with intermittent outbreaks of WSSV since 2005.

It is possible that the shrimp were persistently infected with WSSV and white spot disease was not manifest at the culture temperature of 27 to $29^{\circ} \mathrm{C}$. Thus, WSSV was not detected by PCR even though some shrimp were carriers. To detect dormant infections, farmers, as part of their health monitoring programs, recently began to use cold induction of viral replication by transferring the shrimp to a lower temperature $\left(20\right.$ to $23^{\circ} \mathrm{C}$ ) for 2 to $5 \mathrm{~d}$ and then sampling for WSSV PCR analysis. This practice is based on the theory that a low temperature will weaken the host's defense responses and allow WSSV replication (Vidal et al. 2001). Thus, the viral infections could have persisted in the farmed populations undetected until mortalities became severe.

The genotype data were suggestive of the origin of WSSV on the other 2 infected farms. All of the WSSV isolates from Farms C and D were of the newly discovered WSSV genotype $\left\{7_{125}, \operatorname{del}_{94}\right\}$, suggesting that the outbreaks on these farms originated from a common, but unidentified, source. In some outbreaks, the source of a virus can be determined by genotyping analysis coupled with the history of shrimp introductions, either live or from the commodity market. In isolates from these 2 Saudi Arabian farms, the WSSV genotype is unlike those from other geographic areas. Furthermore, at least one of the farms, Farm C, is known to have brought in wild adult Penaeus indicus from the Red Sea to use as broodstock, so this could be the origin of this new WSSV variant. However, little is known about the distribution of shrimp viruses in natural populations, and most information on the distribution is from disease outbreaks on farms. There is considerable variability in the tandem RUs among WSSV isolates both within and between geographic 


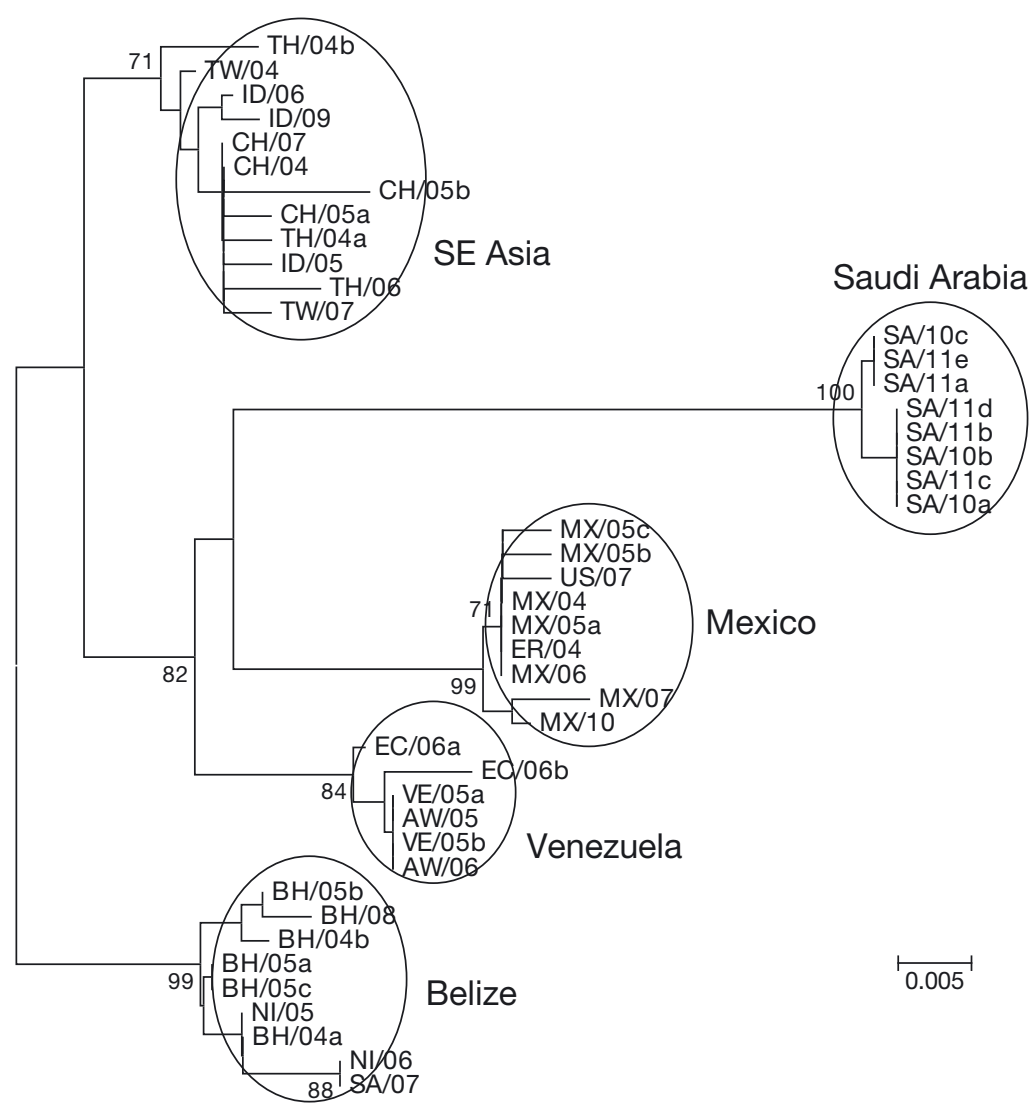

Fig. 4. Phylogenetic tree of TSV based on capsid protein 2 (CP2) amino acid sequence generated by the neighbor-joining method using the MEGA program; numbers indicate percentages of booststrap support from replicates. Name of sequence is indicated by the country/year of isolation. Countries: SA: Saudi Arabia; TH: Thailand; TW: Taiwan; ID: Indonesia; CH: China; MX: Mexico; US: USA; ER: Eritrea; EC: Ecuador; VE: Venezuela; AW: Aruba; BH: Belize; NI: Nicaragua; Years: 04 to 11: 2004 to 2011. Lower case letters indicate different isolates from the same site and year; within the Saudi Arabian lineage, SA/11a and SA/11c were from Farm $C_{i}$ the other 6 isolates were from Farm D

regions. The Saudi Arabian WSSV isolate is unusual and characterized by the deletion of ORF 94.

In this study, we discovered that the isolate of WSSV found in Penaeus monodon from Mozambique also has ORF 94 deleted, suggesting a possible phylogenetic relation, even though the Mozambique and Saudi isolates differ at ORF 125. The Red Sea connects to the Indian Ocean, where shrimp culture is common. The occurrence of the same deletion in ORF 94/95/93 may be explained by the mixing of shrimp subpopulations by southward currents along the east African coast. However, further study is needed to determine whether the ORF 94/95/93 deletion is characteristic for WSSV in wild crustaceans in the waters of this region.

The finding of a genotype with deletion in ORF 94/95/93 suggests that the number of RUs in ORF 94 cannot be used as a marker for all WSSV isolates. ORF 94, ORF 95 and ORF 93 were not all annotated with specific functions (Van Hulten et al. 2001); apparently, these ORFs are not essential for WSSV. Even larger deletions have been found in the WSSV genome, e.g. in ORF $14 / 15$ ( 0.5 to $6 \mathrm{~kb}$ deletion) and in ORF 23/24 (13 kb) (Dieu et al. 2004, Marks et al. 2004), and they have been associated with a higher virulence (Marks et al. 2005). The effect of the deletion in ORF 94/95/93 (1.5 kb) on virulence is not known.

A new TSV genotype was found in Saudi Arabia, and was shown to be distinct from TSV isolates currently found in SE Asia and Latin America. This indicates that the source of TSV in Saudi Arabia is probably not from imported shrimp, contrary to other areas (e.g. Eritrea and Texas, USA), (Wertheim et al. 2009), unless the virus genome has changed substantially in adapting to a new host species (i.e. Penaeus indicus in this case). However, TSV has been found in a number of other penaeid shrimp species and at least one palaemonid shrimp, Macrobrachium rosenbergii, (Nielsen et al. 2005) without an accompanying alteration of the virus genome. TSV was first found in P. vannamei in Ecuador, but it was subsequently found to infect $P$. stylirostris, $P$. japonicus and $P$. monodon (see Table S1 in Wertheim et al. 2009) as well. Isolates cluster based on geographic region and not on the host. It is unlikely that the new TSV genotype evolved as the virus adapted to a different host. Thus, we believe that the new genotype discovered in Saudi Arabia is most likely from wild $P$. indicus stocks from the Red Sea. The 2 affected farms (Farms $\mathrm{C}$ and $\mathrm{D}$ ) are in close proximity to each other, so if a viral disease outbreak occurs at one farm the disease could easily be spread to nearby farms, for example by seabirds (Garza et al. 1997, Vanpatten et al. 2004).

Both new types of WSSV and TSV were found at Farms $\mathrm{C}$ and $\mathrm{D}$, and they were probably from the same origin, the Red Sea. Thus, to exclude these viruses, it is recommended that wild broodstock be frequently monitored by using the most sensitive diagnostic tools, such as PCR (and RT-PCR), to develop specific-pathology-free shrimp, and eventu- 
ally to select for TSV-resistant Penaeus indicus; the resistant lines usually have higher survivals (>80\%) in the farms with incidence of TSV.

\section{LITERATURE CITED}

Benson G (1999) Tandem repeats finder: a program to analyze DNA sequences. Nucleic Acids Res 27:573-580

Dieu BTM, Marks H, Siebenga JJ, Goldbach RW, Zuidema D, Duong TP, Vlak JM (2004) Molecular epidemiology of white spot syndrome virus within Vietnam. J Gen Virol 85:3607-3618

Garza JR, Hasson KW, Poulos BT, Redman RM, White BL, Lightner DV (1997) Demonstration of infectious Taura syndrome virus in the feces of seagulls collected during an epizootic in Texas. J Aquat Anim Health 9: 156-159

Hoa TTT, Oanh DTH, Phuong NT, Preston NJ, Walker PJ (2005) Genotypic variations in tandem repeat DNA segments between ribonucleotide reductase subunit genes of white spot syndrome virus (WSSV) isolates from Vietnam. In: Walker PJ, Lester RG, Bondad-Reantaso MG (eds) Diseases in Asian aquaculture V. Asian Fisheries Society, Fish Health Section, Manila, p 339-351

Holthuis LB (1980) Shrimp and prawn of the world: an annotated catalogue of species of interest to fisheries. FAO species catalog. FAO Fisheries Synopsis 125 (1). FAO, Rome

Huang J, Song XL, Yu J, Yang CH (1994) Baculoviral hypodermal and hematopoietic necrosis-study on the pathogen and pathology of the explosive epidemic disease of shrimp. Mar Fish Res 16:1-10

Inouye K, Miwa S, Oseko N, Nakano H, Kimura T, Momoyama K, Hiraoka M (1994) Mass mortality of cultured kuruma shrimp Penaeus japonicus in Japan in 1993: electron microscopic evidence of the causative virus. Fish Pathol 29:149-158

Lightner DV (2011) Virus diseases of farmed shrimp in the Western Hemisphere (the Americas): a review. J Invertebr Pathol 106:110-130

Lightner DV, Redman RM, Hasson KW, Pantoja CR (1995) Taura syndrome in Penaeus vannamei (Crustacea: Decapoda): gross signs, histopathology and ultrastructure. Dis Aquat Org 21:53-59

Mari J, Poulos BT, Lightner DV, Bonami JR (2002) Shrimp Taura syndrome virus: genomic characterization and similarity with members of the genus Cricket paralysislike viruses. J Gen Virol 83:915-926

- Marks H, Goldbach RW, Vlak JM, van Hulten MCW (2004) Genetic variation among isolates of white spot syndrome virus. Arch Virol 149:673-697

Marks H, van Duijse JJA, Zuidema D, van Hulten MCW, Vlak JM (2005) Fitness and virulence of an ancestral white spot syndrome virus isolate from shrimp. Virus Res 110:9-20

Muller IC, Andrade TPD, Tang-Nelson KFJ, Margues MRF, Lightner DV (2010) Genotying of white spot syndrome virus (WSSV) geographical isolates from Brazil and comparison to other isolates from the Americas. Dis Aquat Org 88:91-98

Musthaq SS, Sudhakaran R, Ahmed VPI, Balasubramanian G, Hameed ASS (2006) Variability in the tandem repetitive DNA sequences of white spot syndrome virus (WSSV) genome and suitability of VP28 gene to detect different isolates of WSSV from India. Aquaculture 256:34-41

- Nielsen L, Sang-oum W, Cheevadhanarak S, Flegel TW (2005) Taura syndrome virus (TSV) in Thailand and its relationship to TSV in China and the Americas. Dis Aquat Org 63:101-106

OIE (Office International des Epizooties/World Animal Health Organization) (2011a) Immediate notification, submitted date: 04/10/2011. OIE, Paris

OIE (Office International des Epizooties/World Animal Health Organization) (2011b) Manual of diagnostic tests for aquatic animals, 7th edn. OIE, Paris

> Pradeep B, Shekar M, Gudkovs N, Karunasagar I, Karunasagar I (2008) Genotyping of white spot syndrome virus prevalence in shrimp farms of India. Dis Aquat Org 78:189-198

> Stentiford GD, Bonami JR, Alday-Sanz V (2009) A critical review of susceptibility of crustaceans to Taura syndrome, yellowhead disease and white spot disease and implications of inclusion of these diseases in European legislation. Aquaculture 291:1-17

- Tamura K, Peterson D, Peterson N, Stecher G, Nei M, Kumar S (2011) MEGA5: molecular evolutionary genetics analysis using maximum likelihood, evolutionary distance, and maximum parsimony methods. Mol Biol Evol 28: 2731-2739

Tang KFJ, Lightner DV (2005) Phylogenetic analysis of Taura syndrome virus isolates collected between 1993 and 2004 and virulence comparison between two isolates representing different genetic variants. Virus Res 112: 69-76

> Van Hulten MCW, Witeveldt J, Peters S, Kloosterboer N and others (2001) The white spot syndrome virus DNA genome sequence. Virology 286:7-22

> Vanpatten KA, Nunan LM, Lightner DV (2004) Seabirds as potential vectors of penaeid shrimp viruses and the development of a surrogate laboratory model utilizing domestic chickens. Aquaculture 241:31-46

Vidal OM, Granja CB, Aranguren F, Brocj JA, Salazar M (2001) A profound effect of hyperthermia on survival of Litopenaeus vannamei juveniles infected with white spot syndrome virus. J World Aquacult Soc 32:364-372

- Walker PJ, Gudkovs N, Mohan CV, Raj VS and others (2011a) Longitudinal disease studies in small-holder black tiger shrimp (Penaeus monodon) ponds in Andhra Pradesh, India. II. Multiple WSSV genotypes associated with disease outbreaks in ponds seeded with uninfected postlarvae. Aquaculture 319:18-24

Walker PJ, Gudkovs N, Pradeep B, Raj VS and others (2011b) Longitudinal disease studies in small-holder black tiger shrimp (Penaeus monodon) ponds in Andhra Pradesh, India. III. A complex dynamic of WSSV infection and WSSV genotype distribution in farmed shrimp and wild crustaceans. Aquaculture 319:319-327

> Wertheim JO, Tang KFJ, Navarro SA, Lightner DV (2009) A quick fuse and the emergence of Taura syndrome virus. Virology 390:324-329

> Wongteerasupaya C, Pungchai P, Withyachumnarnkul B, Boonsaeng V, Panyim S, Flegel TW, Walker PJ (2003) High variation in repetitive DNA fragment length for white spot syndrome virus (WSSV) isolates in Thailand. Dis Aquat Org 54:253-257

Yang F, He J, Lin X, Li Q, Pan D, Zhang X, Xu X (2001) Complete genome sequence of the shrimp white spot bacilliform virus. J Virol 75:11811-11820 